\title{
Yabancı dil öğretiminde yeni bir teknik önerisi: Zihinsel sınıflandırma tekniği
}

\section{Ahmet GEZEK ${ }^{1}$}

\begin{abstract}
APA: Gezek, A. (2020). Yabancı dil öğretiminde yeni bir teknik önerisi: Zihinsel sınıflandırma tekniği. RumeliDE Dil ve Edebiyat Araştırmaları Dergisi, (19), 29-47. DOI: 10.2900o/rumelide.752071.
\end{abstract}

\section{Öz}

Yabancı dil öğretim tekniklerine günümüzün ihtiyaçları doğrultusunda yeni bir bakış açısı sunmaya çalışan bu dil öğretim tekniği, yabancı dilde duyduğumuz ve okuduğumuz sözcüklerin ve ifadelerin, tıpkı anadilimizdeki gibi dildeki kullanım sıklığına göre kendi içinde bir veri tabanı oluşturulmasına ve öğrencinin akıcı bir şekilde konuşmasına katkıda bulunmayı amaçlamaktadır. Zihin haritalama tekniği olarak adlandırılan bu teknikte zihinsel sınıflandırma ile oluşan veri tabanı, tümevarım ve tümdengelim akıl yürütme tekniklerinin yabancı dil öğreniminde farklı aşamalarda birlikte kullanımı ile ortaya çıkmaktadır. Bu teknik, "Yeni bir dil yeni bir dünya inşasıdır" söylemi ile zihinsel merakın geliştirilmesine, öğrenme odaklı bilgi ediniminden keşfetmeye dayalı bilgi edinimine geçiş yapılmasına ve kelime odaklı başlayan yabancı dil öğrenim serüvenini, öğrencinin cümle, konu ve kitap odaklı şeklinde devam ettirmesine olanak sağlamaktadır.

Anahtar kelimeler: Dil öğrenimi, zihinsel sınıflandırma, kullanım sıklığı, yabancı dil, dil tekniği

\section{A new technical proposal in foreign language teaching: Mental classification technique}

\begin{abstract}
This language teaching technique, which tries to present a new perspective in line with the needs of today's foreign language practice methods, aims to create a database in the language according to the usage frequency of the words we hear or the words and expressions in the text we read in the same language as our native language and contribute to the student's fluent speaking. In this method called mind mapping technique, this database, which is formed by mental classification, emerges with the use of inductive and deductive reasoning techniques at different stages in foreign language learning. This technique enables the development of mental curiosity with the discourse of building a new world, a new language, and the transition from learning-oriented knowledge acquisition to exploratory-oriented learning acquisition. Moreover, the student continquisitionues the word-oriented foreign language learning adventure as a sentence-oriented, subject-oriented and book-oriented adventure.
\end{abstract}

Keywords: Language learning, mental classification, frequency of use, foreign language, language technique

1 Arş. Gör., Yalova Üniversitesi, Sosyal Bilimler Enstitüsü, Temel İslam Bilimleri Bölümü, Arap Dili ve Belagati ABD (Yalova, Türkiye) / Dr. Öğrencisi, İstanbul Üniversitesi, Sosyal Bilimler Enstitüsü, Temel İslam Bilimleri Bölümü, Arap Dili ve Belagati ABD (İstanbul, Türkiye), ahmetgezek02@hotmail.com, ORCID ID: oooo-ooo1-5941-9533 [Makale kayıt tarihi: 08.01.2020-kabul tarihi: 20.06.2020; DOI: 10.29000/rumelide.752071] 


\section{Giriş}

Dil, birkaç cümleden oluşan ve sınırlı bir tanımlama ile izah edilemeyecek kadar girift ve çok yönlü bir olgudur. Geçmişten günümüze dek insanların en önemli ortak paydası olan dil, ekonomik, sosyolojik, kültürel vb. hiçbir kıstasla ölçülemeyecek kadar evrensel olmasının yanında içselleştirilen bir fenomendir (Onan, 2013: 76). Yabancı dil öğrenimi, farklı kültür ve toplumları anlamak, yabancı kültür ve toplumlarla iletişim kurmak amacıyla eski çağlardan beri yapılmaktadır. Günümüzde yabancı dil öğrenim yöntem ve teknikleri batıda yenilenip gelişim göstermekte iken doğuda, ya batıdaki metotlar takip edilip uygulanmakta ya da günümüzün ihtiyaçlarıyla yeterince harmanlanmadan klasik yöntem tekniklerle yabancı dil öğrenimi yapılmaktadır.

Dil öğrencileri geçmişte daha çok genel kültürlerini geliştirmek ve zihinsel faaliyetlerini arttırmak amacıyla yabancı dil öğrenmektelerdi. Yabancı dil öğrenimindeki amaç önceden kişinin okuduğunu anlayabilmesi ve yazma becerisini geliştirmesiydi. Günümüzde ise bunlara ek olarak bir iletişim aracı olarak dinleneni anlama ve akıcı bir şekilde konuşma becerilerinin geliştirilmesi eklendi. Bundan yüzyıl kadar önce elit diyebileceğimiz toplumun aydın kesimi yabancı dil öğrenme arzusu içindeyken bugünkü eğitim sisteminde hemen hemen her ülkede yabancı dil zorunlu hale gelmiştir. Bu yüzden eski teknikler günümüzde yetersiz kalmaktadır. Örneğin çok eskilerden beri bir yabancı dili öğrenmenin en kolay yolu öğrenciye o dili konuşturmak olarak bilinmekteydi. Ancak 1980'li ylllarda bilimsel "psiko-linquistique" çalışmaları, öğrenciyi konuşturmanın faydalı olmaktan ziyade dil öğrenimini zorlaştırdığını ortaya koydu (Tarcan, 2004: 3-4). Çünkü öğrenci, söyleyebildiğinden daha fazlasını anlar. Öğrencinin anlama yetisi / algısı konuşma seviyelerinin üstündedir (Karakaya, 2007: 17).

Ortaöğretim ve yükseköğretim kurumlarındaki yabancı dil izlencesi Türkiye'de ders kitapları ile sınırlı kaldığından, kapsamlı araştırmaya dayalı bir çalışma henüz saptanamamıştır (Demircan, 1988: 169). $\mathrm{Bu}$ durum Türkiye'de bir öğrencinin yabancı dil becerilerini ders kitaplarına ek olarak bilimsel bir metotla nasıl takip edeceklerine dair bazı belirsizliklere neden olmaktadır. Ayrıca her öğreticinin kendi kişisel tecrübelerine dayalı bir metot izlemesini de beraberinde getirmektedir. Temelde her dili farklı kılan birtakım özellikler ve dil öğrenimini zor kılan birtakım etkenler olsa da tüm diller ilk aşamada o dili öğrenmeyi amaçlamış kişiye yabancıdır. Her şeyden önce bu yabancılığın getirmiş olduğu endişe, dili yeni öğrenen kimsenin zihninde korku duvarları örülmesine neden olmaktadır. Bu sebeple kişi yabancı dil öğrenmenin zor olduğunu düşünmektedir.

Ayrıca bir kimsenin dil yetisinin beyindeki birden çok merkezin çalışması sonucunda oluştuğu, bu merkezlerin çalışmasının da birbirinden farklı sistemlere dayandığı ve dil formasyonunun bir bütün olarak tek merkezde olmadığı beyin ve dil üzerine yapılan çalışmalar ile ortaya çıkmıştır. Yabancı dil öğreniminde bu gelişmelerin göz ardı edilmemesi önemlidir. Şöyle ki dil formasyonu, dört ana merkez ve bu merkezlere bağlı alt merkezlerin çalışması sonucunda meydana gelmektedir. 1950'lerden beri devam eden bilimsel ve teknolojik gelişmeler, dil eğitimi ve öğretimine yeni boyutlar getirmiş ve beyinle ilgili çalışmalar neticesinde beynin bazı faaliyetlerinin bir haritaya dökülebilmesi dil eğitimine yeni bir veçhe kazandırmıştır (Koç ve diğerleri, 2009: 20). Şöyle ki göz ve göz kaslarının yoğun çalışması neticesinde gözün netlik sahasına giren söz ve söz grupları, zihinde net olarak algılanmaya çalışılır. Göz, görüntüyü ilk olarak görüntü merkezine, oradan da başka bir merkez olan görüntü tanıma merkezine ulaştırır. Daha sonra görüntü yorum alanına giden görüntü, kişinin hafızasındaki bilgilerle karşılaştırılır ve yorumlanarak okuma merkezi tarafından işlem sonuçlanır (Koç ve diğerleri, 2009: 415-416). 
Zihin haritası; beynin düşündüğü ve fikir ürettiği bir süreç olan yayılan düşünmenin grafik gösterimine denir. Özellikle hafıza, yaratıcıllk, öğrenme ve her türlü beyin işlevine uygun, görsel, grafik bir bütüncül düşünme aracı olarak zihin haritası, beynin doğal işlevlerini arttırarak daha güçlü kılar (Buzan ve Buzan, 2018: 31). Zihin haritaları tekniği; düşünceleri oluşturmak, görselleştirmek tasarlamak ve tasnif etmek ile ilintili olarak eğitim alanında, herhangi bir organizasyonda, bir problemi çözmede ve karar alma süreçlerinde kullanılan bir tekniktir. Ayrıca yabancı dil öğretimi dışında Türkçe eğitiminde okuma, dinleme, konuşma ve yazma becerilerinin geliştirilmesine yönelik de kullanılabilmektedir (Onan, 2013: 263). Her ne kadar farklı alan ve disiplinlerdeki kullanımı değişkenlik gösterse de temel de zihin haritalaması, kavramlar arasındaki ilişkilerin belirlenmesine yönelik yapılmaktadır. Örneğin yabancı dil ile ilgili olarak "sinirdilbilimsel yabancı dil öğretim yaklaşımı", beyinde varsayılan bir "içsel haritanın” deneyimlere bağlı olarak değişebileceği üzerine öğretim sistemini kurmuştur (Doğan, 2012: 353). Yabancı dil öğretim yaklaşım ve teknikleri temel alınarak geliştirilen bu teknik ile diğer dil haritalamaları arasında isim ve uygulama benzerlikleri olmasına karşın içerik yönünden bu metodun kendine özgü ve günümüz şartlarına uyarlanabilmiş orijinal tarafları vardır. Şöyle ki bu teknik; yabancı dilde kullanılan kelime ve cümlelerin kullanım sıklığına göre sınıflandırılmasını ve bu kullanım sıklı̆̆ına göre bütüncül bir yaklaşımla zihinsel haritalanmasını amaçlamaktadır. Yabancı dili daha kalıcı bir şekilde öğrenmeyi hedefleyen bu teknik; genel anlamda Arapça ile ilgili son üç yıldır verdiğimiz derslerde öğrencilerin karşılaştığı problemler göz önünde tutularak derlenmiştir. Ayrıca İngilizce dilini geliştiren meslektaşlarımızın karşılaştığı zorluklar da göz ardı edilmemiştir.

Bu çalışmada, yabancı dil öğretim yöntemlerinin en eskisi ve yaygını olarak kabul edilen dilbilgisiçeviri yöntemi (Doğan, 2012: 61) ve daha sonra geliştirilen modern yabancı dil öğretim yöntemleri ve yaklaşımları incelenmiştir. Bir yöntem ve yaklaşıma bağlı kalmak, öğretimin belirli teknik ve araçlarla yapılmasını ve çoğu zaman istenmedik bir alana sıkışmasına neden olacağından (Doğan, 2012: 202) bu çalışmada seçmeci bir yaklaşım sergilenmiştir.

\section{Dilde zihin haritalamasının temelleri}

Modern dil bilimine göre dil, cümlede var olan kelimelerin şekil ve sentaks organizasyonu olarak tarif edilir (Karakaya, 2007: 74). Bir dil ile ilgili bilgi edinmiş olan kişi, belli bir biçimde ses ile anlamı birbirine bağlayan kurallar dizgesini içselleştirmiş olmaktadır. Dilbilimci aslında bu içselleştirilen dizgeye ilişkin bir varsayım öne sürer. Şüphesiz bu varsayımlarla eksiksiz bir dilbilgisi kurmaya çalışan dilbilimci, dilin iç içine geçmiş ve tek olmayan temel bir etmenini incelemektedir (Chomsky, 2002: 47).

Fahreddin er-Râzîye (ö.606/1210) göre lafızların tayin olunduğu şey zihni suretlerdir. Lafzın delalet ettiği mana ile kastedilen harici mevcudatın zihindeki suretleridir (Güler, 2015: 474). Modern dilbilimin kurucularından Ferdinand de Saussure'e (ö.1913) göre dil sadece bir ad dizgesi değil, bir kelimenin anlamı ya da anlamın görüntüsü gösterilen'dir. Bu gösterilen şey, aynı dil dizgesi içindeki bir sözcükle diğer sözcükler arasındaki ilişkiyi belirleyen anlam bilimsel ilişkinin bir ürünüdür. Aslında dil bir dizge olup bu dizgedeki olgular parça parça değil, bir bütün olarak incelenmelidirler. Dildeki her ayrıntının yerinin dizgenin tümü tarafından belirlendiği daima göz önünde bulundurulmalıdır. Ses imgeleri / çağrışımları, gönderme yaptıkları nesneler arasında bağıntı kurar (Kılıç, 2002: 24-25). Yine Étienne Bonnot de Condillac’a (ö.1780) göre birtakım imgesel çağrışımlar olmadan "dil-öncesi” veya dilden bağımsız bir düşünme etkinliği imkansızdır. Zihin çevresel ve fizyolojik uyaranlara tabi olur. $\mathrm{Bu}$ 
sebeple dil sadece düşüncenin ifade vasıtası değil, aynı zamanda düşüncelerin denetim ve analiz mekanizmasıdır (Altınörs, 2014: 34).

Yabancı dil; dinleme, okuma, konuşma ve yazma dört temel dil becerisi ile öğrenilir. Bu temel yabancı dil kullanma becerileri, yabancı dili ayakta tutan sütunlar olup bunların işlevsel bütünlüğünden oluşan bir yapı dili öğrendikçe karşımıza çıkar (Aktaş ve İşigüzel, 2013: 37). Buradaki zihin haritalama tekniği, dilin işleyiş̧indeki karmaşıklıktan hareketle yabancı dili kalıcı hafıza / bilinçaltı tekniği ile öğrenme şeklidir (Doğan, 2012: 304-305). Zihnin bilinç üstündeki işleyişi her ne kadar kişiden kişiye farklılık gösterse de bilinçaltında bu durum değişkenlik göstermez. Zihin haritalama tekniği bir dil teorisi ortaya koymaz, aksine dilin ne olduğu konusunda doğrulanamayan kavramlar (Karakaya, 2007: 16.) yerine var olan teori ve düşünceleri daha pratik hale getirmeyi amaçlar. Bu teknik, dili en doğal şekliyle öğrenmeyi hedefleyerek diğer yabancı dil öğrenim yaklaşım ve teknikleriyle bu noktada benzerlik arz eder (Doğan, 2012: 406). ${ }^{2}$ Dahası hedeflenen dili öğrenmenin ötesinde zihin haritalamada amaç, öğrenilen yabancı dille birlikte yeni bir dünya inşa etmek ve o dünyayı keşfetmektir (Doğan, 2012: 280).3 Bu teknikte asıl olan, öğrenimi hedeflenen yabancı dildeki mana ve mefhumlar iken kelime ve terkipler, bu teknikte geçici ikincil bir öneme haizdir. Kelime ve kelime öbekleri, bir ağacın yaprakları gibidir.

Dil, şeylerin içsel tabiatını ifade etmede yetersiz olması dolayısıyla Platon (m.ö.347), düşünceleri dile emanet etmenin doğru bir davranış olmadığını vurgular (Altınörs, 2014: 33). Dili besleyen ve geliştiren şey düşüncedir. Bütün değerlerde olduğu gibi, dilin birimlerini oluşturan şeyin de doğası maddi değildir. Dilin bu kendine has doğası ne olursa olsun, bir değerler sistemi olarak aynı tüm diğer göstergeler gibi olgunun konumunu sabitler (Saussure, 2014: 281-284). Zihin haritalama tekniği tam da bu göstergelerin yabancı dilde oluşması, gelişmesi ve haritalanması üzerine yoğunlaşır. Dil, zihinde var olan mana ve suretleri muhataba iletir. Nasıl ki bir şehrin tek bir sokağına, evine veya şehrin içindeki bir parçaya değil de ancak şehrin manzarasına uzaktan bakıldığında onun yapısı, mimarisi, doğal güzellikleri ve konumu beynimiz tarafından haritalanabiliyorsa, kelime ve kelime gruplarının da zihnimizdeki durumu buna benzer. Yabancı dil de hiç alışık olmadığımız kelime ve cümleler ilk başta manzaranın ortaya çıkmasına mâni olsa da kelimelerin anlamları öğrenildikten sonra bu manzarayı görmemizin önündeki engel kalkmaktadır. Burada sadece yabancı dil öğrenirken tümevarım ile mana çıkarımı yapmaya çalışan zihni tümdengelim ile zihinsel haritalama yapmaya alıştırmamız yeterlidir. $\mathrm{Bu}$ tür bir tümdengelim tekniği, hem yabancı dilde yeni öğrendiğimiz kelimelerin anlamlarını belirlemeye yönelik olarak tasarrufta bulunmamızı / inisiyatif almamızı sağlayacak hem de o kelimelerin hakiki mi yoksa mecazi mi olduğu noktasında bize ipucu verecektir. Nitekim sözcüklerde oluşan farklı mana olguları ve varyasyonlar metnin bütünselliği içinde gizlidir.

Rus Fizyolog İvan Petroviç Pavlov (ö.1936) insandaki dilin gelişimini hayvanlarla eş değer olan sembol-anlam aşamasından sonraki ikinci aşamasını işaret sistemleri ile açılklar. İşaret sistemleri ile konuşulmaya başlandığını son aşamada ise insanın en yüksek düşünce fikrine yetişerek zihninde şekiller oluştuğunu ileri sürer. Dil ve düşünce gelişiminde tecrübe ve tecrübenin rolünü vurgular. Öte yandan Lev Semenovich Vygotsky (ö. 1934) düşünce ile konuşma arasındaki ilişkinin daimi olmadığını yani aynı düzlemde gelişme göstermediklerini ileri sürer. İnsanda hem zihin öncesi hem de dil öncesi konuşma olduğunu düşünür (Karakaya, 2007: 21). Saussure ise dilin besbelli olguların sahnesi olduğunu, bu olguların incelendiğinde koşulların doğasının pek az sorgulandığını düşünür (Saussure, 2014: 275). İşte bu işaret sistemleri ile zihinde oluşan şekiller ve olgular, dillerin temelleri ve

İçerik merkezli dil öğretim yaklaşımında dilin “daldırma yöntemiyle” ve ezbere başvurmadan öğretilmesine dair bk. Sessiz dil öğretim yönteminde keşif ve tahmin yeteneklerinin kullanımı ile ilgili olarak bk. 
asıllarıdır. Kanaatimizce tıpkı anadilde olduğu gibi yabancı dilin gelişimi için bu asılların ve sembollerin güçlendirilmesi gerekir (Doğan, 2012: 172).

Alman filozof Ernsst Cassirer (ö.1945) ise insanı diğer filozoflar gibi "akıllı hayvan” olarak değil, "simgeleştiren hayvan" (animal symbolicum) şeklinde tanımlamayı yeğler. Çünkü akıl, bütün zenginliği ve çeşitliliği içinde kültür hayatının kavranabilmesi için elverişli değildir. Simgeleştirme, insanın karakteristik özelliğini belirten ve medeniyet yolunda yürüyüşünü kavramayı kolaylaştıran bir ıstılahtır (Altıörs, 2014: 25). Diller, bir koda dayanır (Barthes, 2013: 232). Cassirer' göre insan idrakindeki şekiller sembolik şekillerdir. İnsanı akıllı bir varlık olarak tarif etmek yerine onu sembolleştiren bir varlık olarak tarif edebiliriz. Bu şekilde insanın farklılıklarını belirleyebilir, onu anlayabiliriz. İnsan hayatının en karakteristik özelliklerinden biri sembolik düşünce ve sembolik davranıştır. Hatta insanlık kültürü bu şartlara ve özelliklere dayanır. Konuşurken ve akıl yürütürken sembolleri kullanmak ve bu sembollerin özüne yönelerek temellerini bulmaya çalışmak ana noktadır (Karakaya, 2007: 47.

Dil ve anlam teorisinde Locke, bir sözcüğün anlamının onu kullanan kişinin zihninde yerini tutan idea / fikir olduğunu, kapalı halde bulunan ideaları / fikirleri, en kullanışlı vasıta olan ve eklemli seslerden oluşan kelimeler ile dışa vurduğumuzu belirtir. Kelimenin doğru anlamı sadece zihnimizdeki bir idea olabilir. René Descartes (ö.1650) ve Gottfried Leibniz’e (ö.1716) göre ise anlam, idealarımız ve irademizin karışımı ile ortaya çıkan fiili kavrayışlarımızdır (Altınörs, 2014: 60). Zihindeki suretin / mananın harici mevcudata delaleti doğal ve zaruridir. Dil ve yazı toplumdan topluma farklılık gösterdiği halde suretler ve manalar evrenseldir (Güler, 2015: 430-432). Zihnimiz mana ve mefhumlar ile düşünürken kelimeler ve cümleler o mana ve mefhumları yansıtan aynalar gibidir. Zihin haritalama tekniğinde ise, dildeki her türlü lafzi zorlamaya karşı yabancı dilde anlam derinliğine ulaşmayı ve tıpkı anadilimizdeki gibi öğrendiğimiz dili sembolleştirmeyi hedefler.

$\mathrm{Bu}$ hedef, kelime veya kelime topluluklarının sözlük anlamlarının ötesinde kelimenin belirtme, gösterme ve adlandırma özelliğine suretleri / çağrışımları ekleyerek olur (Onan, 2013: 141). Bir sözün ses, biçim ve anlamca başka sözlerle kurduğu bağlantılar, sözün çağrışım sahasıdır. Bu sahada herkes, sözleri kendi dünya görüşlerine göre ayrı bir komşuluk ilişkisi içine sokar. Bir sözü farklı bir söz ile ilişkilendirir (Karaağaç, 2013: 206). Dilin farklı aşamaları vardır. Sadece kelimelerin anlamlarını bilmek cümleyi anlamak için yeterli olmayabilir. Şöyle ki öğrenilen dilin dünyasını tanımak cümleyi anlama noktasında önemli bir etkendir. Dolayısıyla yabancı dilde anlamın güçlenmesi, cümlelerdeki suretlerin / resimlerin belirginleşmesi için gerekli bir durumdur. Zira kelimeler her ne kadar sınırlı olsa da kelimelerin zihinde var olan suretleri sinırsizdır.

Dahası Pascal Picq'e göre dil, birbirleri arasında kombine edilen duyular birimlerinin, bir sentaksa uygun bir tarzda sınırsız sayıda beyan oluşturmayı mümkün kılan sınırı bir sistemdir. Aynı zamanda dil, işaret ettiği şeylere keyfi olarak bağlı sembollerden meydana gelir ve sinırlı unsurlar ile sınırsız sayıda cümle oluşturmaya imkân veren bir tertibattır (Altınörs, 2014: 23). Descartes'in da vurguladığı gibi dil, bir yandan muhakemeyi sevk ve idare neticesinde varılan hükümleri açılamaya imkan verirken diğer yandan düşüncelerin, teessürlerin ve duyguların ifadesinde az çok aslını bozar (Altınörs, 2014: 25). Bir kelime ancak onu kullananlardan her an aldığı onayla ve yerleşilen görüş açısı ile var olur. Kelimeyi ses dizesinden farklı kılan ve aynı ses dizesinden meydana gelse bile bir başka sözcükten ayıran da budur. Bir sözcüğün yeri ve gerçeklik kazandığı alan, kendi anlamına sahip olduğu tek yer olan zihindir. Dil ile dilin iletimi arasında muhtemel anlam bulanıklığı gözlemlenmeden dil veya dil yetisi sözcüğü hiçbir şekilde telaffuz edilemez (Saussure, 2014: 91-94). 
Dil zora, bolluğa ve aceleye gelmez. Her yeni kelime tıpkı bir çocuk gibi şefkate ve olgunluğa erişebilmesi için emeğe muhtaçtır. Aslında dillerle ilgili ileri sürülen zorluk/kolaylık, ilkellik/gelişmişlik, güzel/çirkin vb. ifade tarzları doğru değildir. Çünkü her dil, onu kullanan toplumun ihtiyaç ve şartlarına göre yeterince gelişmiştir (Kayaalp, 2006: 68). Bir dilde sosyoloji, psikoloji, antropoloji ve benzeri bilim dalları göz ardı edilemez. Gerçekte dil kültürle birlikte vardır (Kayaalp, 2006: 123). Şöyle ki bir dili konuşan insanların nasıl sevindiklerini, nasıl üzüldüklerini, nasıl hayret hayrete düştüklerini, nasıl şaka yaptıklarını, muhataplarını nasıl övüp nasıl yerdiklerini, kısaca hayattaki değişken ruh hallerini dillerine nasıl yansıttıklarını önemsemeden bir dili öğrenmek o dilin ruhundan uzaklaşmak demektir. Bu durumda yabancı dil, hissedilmeyen ama öğrenilmesi gereken bir zorunluluk halini alarak kişiyi kendisinden uzaklaştırır ve zamanla kişiye bıkkınlık verir. Halbuki bir yabancı dil öğrenildikçe kişiye mutluluk vermesi, bazen hüzünlendirmesi bazen kişiyi hayrete düşürmesi, kısacası tıpkı doğal dil öğretim yönteminde olduğu gibi (Doğan, 2012: 91) kişinin kendi anadili vasıtası ile yaşadığı duygu ve düşünce gelişimini yaşatması gerekir. Lakin ezberlenen kelimeler ve gramer kurallarına göre cümle kuma çabaları, üstüne sinavlarla yabancı dil seviyesinin belirli periyotlarla eğitim sistemlerince ölçülmesinin teşviki, yabancı dil öğrenimi amacından saptırmış ve bu durum öğrencide dile karşı stabil ve soğuk bir tavır sergilenmesine sebebiyet vermiştir.

Dilde insanın içinde bulunduğu ortamın maddi ve manevi bütün değerleri göz önünde tutulmak zorundadır (Kayaalp, 2006: 123). Örneğin Arap dilinin klasik ve modern olarak ikiye ayrılması yaygın bir durumdur. Klasik Arapçayı modern olandan ayıran en önemli husus mana ve cümle kurulumlarıdır. Lafız açısından her iki türden metinler incelendiğinde modern Arapçada kullanılan kelimeler daha fazla olmasına karşın, klasik metinlerin anlaşılmasının daha zor olduğu belirtilir. Bazıları tarafından ise bunun sebeplerinden biri, acemlerin yazdıkları klasik metinlerin dolambaçlı ve çetrefilli olması gösterilir. Gerçekte sebep, klasik metinleri yazanların acem veya Arap olması değil bilakis klasik metinlerde var olan cümle terkiplerdeki mana yoğunluğudur. Zira dilin beliğ / sanatsal olması birçok kelimenin birbiri ardınca dizilmesi ile değil, birbiri ardınca dizilen kelimelerdeki mana derinliği ile olur.

Klasik dönemdeki İslam alimlerinin deruni düşünceye sahip olmalarından ötürü yazdıkları metinlerin anlaşılması günümüzde olduğu gibi yaşadıkları dönemde de zordu. Bu yüzden kendi dönemlerinden itibaren yazdıkları eserler üzerine şerh ve haşiyeler yazılmıştı. Ayrıca günümüzde modern Arapçanın daha sade ve anlatılmak istenen mana ciheti ile daha basit görülmesi dili kullananların duygu ve düşüncelerini yansıtırken ki tercihlerinden ve dili kendine özgü kullanma biçimlerinden kaynaklıdır. Örneğin Seyyid Kutub (ö.1966) ve Muhammed Said Ramazan el-Bûtî (ö.2013) gibi bazı modern düşünürler yirminci asırda yaşamalarına rağmen ifade tarzlarında / üsluplarında sıkça anlaşılması güç kullanımlara ve çetrefilli ifadelere rastlanmaktadır.

\section{Kullanım sıklığına göre zihin haritalaması yaparak dil öğrenimi}

Beynimiz yaptıklarımız kadar yapmadıklarımız tarafından da yönlendirilir. Öğrenmenin en kalıcı yolu beynin öğrenme işlevselliğini geliştirmektir. Bir dili, kişinin kendi ihtiyaçları doğrultusunda ve kendi çalışma sistemine uygun bir şekilde (Koç ve diğerleri, 2009: 500) öğrenmesi esastır. Yapı taslağı bakımından dilin ortak merkezli dairelerden oluşan bir örgütsel yapılanması vardır. Her dilin merkezindeki bu sistem; dilin kuruluşu, modeli, düzeni ve bu düzene göre dil öğelerinin dizilimi ve karşılıklı durumunu ifade eder. İşte bir dili anadili gibi konuşanların "dil bilinci” veya "dil duygusu" buna dayanır (Kayaalp, 2006: 66). Yabancı dilde ise ilk olarak kelimeler öğrenilir, sonra cümleler anlamlandırılır. Daha sonra cümlelerden oluşan bir paragrafın ve paragrafların anlaşılması için çaba 
harcanır. Yabancı dilini aşama aşama geliştiren kişi sonunda hacimli bir kitabı anlayacak seviyeye ulaşır. Yabancı dilde kelimeler öğrenilmeden cümleyi veya paragrafı anlamaya çalışmak klasik dil öğreniminde yanlış olarak görüldüğünden, yabancı dil öğretiminde prensip olarak bu hiyerarşiye uyulur.

Bir kimsenin anadilinde geçirdiği evreler göz önüne alındığında yabancı dil öğrenen bir kimsenin şu dört evreden geçeceğini söylemek mümkündür.

a. İlk evre: Kelimeler: He türden dilsel olgunun koșulu, en az iki unsur arasında geçmesidir (Saussure, 2014: 127; Karaağaç, 2013: 206). Bu evredeki kişi yabancı dil öğrenim merhalelerinden ilkinde olup kelimelerin anlamlarını öğrenirken, yan yana gelen iki veya daha çok kelimeyi anlamlandırmakta zorluk çeker. Henüz uzun cümle veya paragrafları anlayamaz. Çünkü zihinde kelimelerin diziliminden meydana gelen büyük fotoğraflar / hikayeler henüz oluşmamıştır. Bu suret ve manaların oluşması için kişinin bir süre sonra dilin ikinci evresine geçiş yapması gereklidir.

b. İkinci evre: Uzun cümle ve paragraflar: Zihin haritalama tekniğine göre bu evrede, sözlüğe bakılarak yapılan "kelime odaklı cümleyi anlamlandırma" dil metodu zaman kaybına yol açtığından öncelikle zihnin uzun terkiplere alıştırılması hedeflenir. Nasıl ki cümle basit bir sözler dizisi değilse, metin de sadece bir cümleler dizisi değildir. Örneğin "Dokuma" ve "kumaş" manalarına gelen metin sözü, geniş anlamıyla birden çok katılanın ve birden çok öğenin oluşturduğu bütünün adıdır. Kumaşın ipliklerden dokunması ile oluştuğu gibi metin de kendisini oluşturan öğelerin birbirine eklenmesi ile oluşur (Karaağaç, 2013: 398). Dilin bu aşamasında daha önceden bilinen kelimeler cümlenin anlaşılması için ipucu verse de cümlelerde var olan hakikat mecaz veya kinaye olguları mananın anlaşılması önünde hala engel olarak durmaktadır. Zaten cümlede var olan tüm kelimelerin anlamlarına sözlükten bakılsa bile, bir kelimenin birden çok anlamı olması, bu anlamda birden çok duygu oluşu ve bağlamın daima göz önünde bulundurulması öğrenciyi seçim yapma noktasında kararsız bırakır. Bu noktada anlamı bilinmeyen kelime ve terkipler üzerinde düşünüp fikir yürütmek ve zihni tanışıklığın sağlanması akabinde kelimenin lügate bakılacağı zamanı beklemek direk lügate bakıp kelimenin anlamını öğrenmekten daha kalıcı olmaktadır (Doğan, 2012: 164). Yani ilk önce kelimelerle tanışmak lazımdır. Burada kelimenin sözlüğe bakılacağı zaman, kelime ve terkiplerle tanışıklığın sağlanması ve artık o kelime ile karşılaşıldığında adeta o kelimenin "benim için sözlüğe bak" demesi olarak belirlenebilir. Amaç, hedef dildeki fikir ve düşünceleri anlamak olduğundan, belli bir süre bu aşamada geçirildikten sonra dilin üçüncü evresine doğru geçiş yapılması gerekir.

Bir dil ile ilgili bilgi ve dil bilgisi, dilbilgisinin şekli konusunda ancak keskin sınırlamaları olan bir "önceden ayarlanmış" düzen tarafından edinilebilir gibi görünmektedir. Kant'ın verdiği anlamda doğuştan gelen bu sınırlamalar dil ediniminin bir önkoşuludur ve dil öğrenmenin sonucunu belirlemede en önemli etkenin bu olduğu anlaşılmaktadır (Chomsky, 2002: 136).

Okuyucu, parçadan bütüne yaklaşımda olduğu gibi sadece ses, harf, hece, kelime ve kelime gruplarını öğrenerek okuma becerisi kazanmaz. Aynı şekilde sadece kısa metin ve cümlelerden hareket etmek de yeterli olmaz (Onan, 2013: 141). İnteraktif yaklaşımda olduğu gibi bu teknikte de okuma süreçleri eşgüdümlü / paralel şekilde devam eder. Zira ilk aşamada kelime ve parçalar ile dil öğrenmeye başlayan öğrenci ikinci seviyeden itibaren bütünden parçalara doğru bir yaklaşım içinde tümdengelim metodunda tüm seviyelerde okuma ve dinleme sürecine başlar. Çünkü zihin edindiği bilgi parçacıklarından bir suret meydana getiremezse öğrendiği bilgiler hafızaya yük olur ve dahası kalıcı olmaz.

c. Üçüncü evre: Kitap okuma, teorileri anlama ve fikir edinme: Bu evrede kişi, tıpkı anadilinde olduğu gibi mana ve suretlerle düşündüğünden dolayı bilmediği kelime veya cümleleri önemsemeden / takılıp kalmadan kuş bakışı metindeki veya dinlediği konudaki ana fikre odaklanır. Özellikle tanışıklık sağlamadığı kelime veya kelime öbeklerini ana fikre zarar vermediği sürece üzerinde durmadan geçer. Çünkü zihnimiz ilk defa gördüğü kelime terkipler ile inilti kurmadan / fikir yürütmeden anlamını öğrense de unutur. Ayrıca bu evrede zihinde var olan kurguyu 
anadilimizdeki hıza çıkartmamız önceliktir (Doğan, 2012: 159).4 Kişi metindeki ana fikre yoğunlaşarak anadilde oluşturduğu anlama kapasitesi ve hıza denk bir çabukluğa ulaşabilir.

Anadilimizde bile konuşma hızı ile düşünce hızı eşgüdümlü / paralel seyretmemesinden ötürü dinleyici konuşmanın bazı bölümlerini kaçırabilir. Örneğin insan bir dakika içerisinde ortalama 125 sözcük konuşmasına karşın düşünürken bu ortalama, 500 sözcük civarında olur. Her ne kadar bu konu ile ilgili farklı kaynaklar olsa da (Koç ve diğerleri, 2009: 452) bu durum dinleme hızının konuşma hızından daha yüksek olduğu hakikatini değiştirmez. Yapılan araştırmalar, başkalarına göre kendimizle beş kat daha fazla konuştuğumuzu ortaya çıkarmıştır (Onan, 2013: 87). Öyleyse yabancı dilde dinlediğimiz manaların bazı bölümlerinin anlaşılmaması ve gözden kaçması normal karşılanmalıdır. Zihni imgeler oluştukça anlama hızı artmaktadır.

Yukarıda ifade edilen uygulamalar ana fikre hiç ulaştırmadığında şöyle bir uygulama tarzına geçilebilir: Eğer metindeki cümle ve terkipler ana fikre odaklanmaya izin vermiyorsa o zaman kişi cümleyi küçük öğelere / parçalara ayırıp her parçayı ayrı anlamaya çalışıp sonra bu parçaları birleştirerek metindeki büyük sureti algılayabilir. Aslında ilk seviye dışında, gördüğümüz kelimelerin anlamlarıyla ilgili bir fikrimiz yoksa, anlamın bilsek de o kelime bize yabancıdır. Önemli olan kelimeleri tutan ve besleyen mana ve fikirleri tıpkı anadilimizde olduğu gibi güçlendirmektir. Şöyle ki kendi dilimizde kelimeler ile değil, resim ve hikayeler ile düşünürüz. Bu teknikte, ilk aşamadan sonraki aşamalarda bu resim / hikâye bağlamında dil öğrenimi esastır.

İletişimin gerçekleşmesinde önemli rol oynayan etmenlerden biri de bağlamdır. Bağlantılı birimlerin toplamına bağlam denildiği gibi (Karaağaç, 2013: 188) bağlamı, içinde dilsel birimlerin kullanıldığı toplumsal durum olarak anlamamız mümkündür. Bir dil kullanımının taşıdığı özelliklerin toplamı bağlamdır (Karaağaç, 2013:188). Bağlam fiziksel bileşenlerin yanında, gönderici ile alıcının kimlikleri ve insan zihninde yer eden çok geniş bir ruhsal oluşum olup dilin sonsuzluğunu ifade eder. Kısaca bağlam veriden uzaktır ve sadece seçilir. Bir metnin anlam bileşenleri o metnin anlam bütünlüğünü oluşturur. Metinler kullanıldıkları veya okundukları bağlamlara göre anlam ifade ederler (Kılıç, 2002: 13-14). Bir mesajın hedefine ulaşabilmesi için bir bağlamı / konteksti olmalıdır (Altınörs, 2014: 23; Doğan, 2012: 407). Mesela Amerika'da üniversite okuyabilmek için TOEFL sınavına giren öğrencilerin sınavdan aldıkları sonuçlar incelendiğinde başarılı öğrencilerin ders dışında önemli ölçüde hikâye ve roman okudukları tespit edilmiş dahası hikâye ve roman okumanın tek başına \%49 oranında genel İngilizce dilini güçlendirdiği saptanmıştır (Işık, 2013: 43-44). Öğrenilen yabancı dil üzerinde zihnin güçlü haritalama yapmaya alışırken, özellikle üçüncü veya dördüncü seviyelerde birçok metin / kitap ve dinleme konusunun tam anlaşılmaması veya bazen çoğunlukla anlaşılmaması normaldir. Ama dördüncü aşamaya çıkmak uğruna birçok kitap ve dinleme konusu anlam noktasında heba oluyormuş gibi gözükse de yapılan dinlemelerin ve okumaların boşuna gitmediği bir süre sonra ortaya çıkacaktır.

d. Dördüncü evre: Yazma, üretme ve teori kurma: Belirtilen bu üç aşama sonucunda kişi tıpkı kendi anadilindeki seviyesine ulaşabilir ve böylelikle öğrenci anadiliyle oluşturduğu zihni dünyanın yanına yeni bir dünya inşa eder ve bu dünya onun için yük olmaktan çok, sınırsız ve adeta keşfedilmeyi bekleyen bilinmezlerle dolu bir dünya olur. Diğer bir deyişle kişi öteki bir dilde var olur. Yabancı dil okuma ve dinlemenin güzelliği ve mutluluğu en çok bu seviyede kendisini gösterir ve onlarca yarım anlaşılan kitap ve dinleme içeriklerinin sonucunda yabancı dilde metnin resmettiği suretler tam olarak kendini göstermeye başlar.

Hafızada çok kısıtlı sayıda cümle bulunmasına karşın hafıza hazır binlerce sözcük taşır. Sözcükler ilk var olurken cümlenin öğesi olarak var olmazlar (Saussure, 2014: 123). Yukarıda da değinildiği üzere

$4 \quad$ Okumalı dil öğretim yönteminde okuma hızı ve yoğun okumalar ile ilgili olarak bk.

Kurklareli University, Faculty of Arts and Sciences, Department of Turkish Language and Literature, Kayalı Campus-Kırklareli/TURKEY e-mail: editor@rumelide.com 
hafızamızda var olan bu sözcükler ile "zihinsel kullanım sıklı̆ı veri tabanı" oluşması için zihnimizin öncelikle haritalama yapması gerekir. Böylece zihnimiz ihtiyaç duyduğu bilgileri almayı / elde etmeyi öğrenir (Doğan, 2012: 410-411). Burada belirtilen her aşamanın kendisinden önceki aşamayı güçlendirici bir rolü olduğundan zihin bir aşamaya alıştığında bir sonraki aşamaya geçmek, dil öğrenimini maksimum düzeyde hızlandırır. Dolayısıyla her aşama bir sonraki aşamada gösterilen çaba ile güçlendiğinden bütün aşamaların iç içe olduğu böyle bir tekniği izlemek daha uygundur.

Dil öğrenimini bir ağaca benzetirsek; yukarıda belirtilen dört aşamadan ilki ağacın kökleri gibi olup ikinci aşama da ağacın gövdesidir. Yabancı dil, bu ilk iki aşamada gelişim gösterip kendi ayakları üzerinde durur. Üçüncü aşama, bu ağacın dalları gibi olup dördüncü aşama ise ağacın yapraklarına benzetilebilir. Üçüncü ve dördüncü aşamada dilin güzelliği ve estetiği kendisini izhar eder. Edebi dille oluşan duygusal etki, çarpıcı hayal ve buna bağlı her türlü yeni anlamla kelimenin manası genişler, derinleşir ve çoğalır. Dış dünyadan alınan malzemeler ile zihinde çağrışma yapan izlenimler ve algılarla iç dünyada / zihinde görüntüler oluşur. İşte bu görüntülere imge denir (Onan, 2013: 141). İmge, fikirden fazlası olup kaynaşmış fikirler girdabıdır ve enerjiyle donatılmıştır ( $\mathrm{Su}, 2004$ : 182).

Dilin güzelliğini ve inceliklerini anlayabilmek için ilk iki aşamada metni anlamlandırma sürecini tamamlamak lazımdır. Aksi takdirde yabancı dil, en baştan bize gösterdiği soğuk yüzünden yıllar geçse de vazgeçmez. Zihin haritalama tekniğinde hedef, zihnin merak ve ihtiyaçları göz önünde bulundurularak öğrenilmiş ve stabil dilden, dilin estetik ve beliğ yönüne doğru geçebilmektir. Çünkü meraktan yoksun bir şekilde edinilen bilgi özümsenemez ve ezberlenir. Zihnin özümsemediği ve hafızaya yük olan bilgiler uzun vadede kişiyi huzursuz eder. Mana ve mefhumların / suretlerin balık ağı gibi oldukları düşünüldüğünde, dil öğrenimi sürecinde hangi aşamada dolaşırlarsa ve bu aşamalardaki konular ne kadar çeşitli olursa, o derece kelime bu ağa takılarak zihinde yer edinir. Özetle her aşamada / seviyede belli bir süre geçirildikten sonra daha sonraki aşamalarda edebi okumalar yapilır.

\section{Kullanım sıklığına göre zihin haritalaması yaparak yabancı kelimelerin öğrenilmesi}

Tüm diller en az on binlerce hatta yüz binlerce kelime ihtiva etmeleriyle birlikte bu kelimelerin kullanım sıklığı elbette aynı oranda değildir. Zira bu kelimelerin bazısı metinlerde çok kullanılırken bazısı orta derecede kullanılmaktadır. Yine bu kelimeler arasında az kullanımı olanlar ile nadir kullanımı olanlar vardır. Mesela dillerde kullanım sıklığı en yüksek olan sözlük birimleri zamirler olup zamirleri ad durum ekleri, çekim edatları, akrabalık ve ilişki adları ve yapım ekleri vb. takip eder (Karaağaç, 2013: 495). Ĕ̆er kişi, haritalama yapmadan tüm kelimeleri öğrenmeye ve ezberlemeye çalışır veya karşılaştığı her kelimede sözlüğe bakarsa, zihin bu kelimeler arasında sık kullanılanlar ile az kullanılanlar arasında ayrım yapamadığından okunan metnin veya dinlenen içeriğin ana teması bozulur. Bundan başka hafıza tüm kelimelere aynı önemi verdiğinden kelimeler unutulurken de hepsi aynı şekilde unutuluverir.

Halbuki zihnimiz sık kullanılan kelimeler ile az kullanılan kelimeler arasında tahmin etme kabiliyetini geliştirmiş olması ve az önemli olan ile çok önemli olan kelime ve terkipleri algılayabilmesi gerekir. $\mathrm{Bu}$ algı ise yukarıda zikredilen aşamaların oluşması ile mümkün olur. Zaten cümledeki kelime ve terkipler ile ilgili "anlamı şudur" veya "anlamı bu olabilir" şeklinde tahmin yürüterek düşünme yapmadan dil gelişim göstermez. Yabancı dil öğreniminde ilk aşamada konuşmaya yönelik sık sı yapılan harici müdahale, öğrencinin özellikle eş anlamlı kelimeler arasında tahmin yürütme ve tercih yapma kabiliyetini köreltebilir. Bu noktada tahmin etme kabiliyetini geliştirmek ve konuşmaya sonraki 
aşamalarda ağırlık vermek ve bu beceriyi ilerleyen seviyelerde geliştirmek daha yararlıdır. Gerçekte dil öğrenen kimsenin birinci aşamadan sonraki okumaları ve çalışmaları zamanla bir sınıflandırma meydana getireceğinden diğer aşamalarda zihinsel sınıflandırma oluştuktan sonra sözlüğe bakılması daha doğrudur.

Dil konusunda en çok hata yapanlardan biri, dili tarihten, kültürden, toplumdan yani insandan ayıran dilcilerdir. Oysa bir toplumdaki fertler kelime ve gramer kuralları üzerine kafa yormadan evlerde, kahvehanelerde, sokaklarda vb. sabahtan akşama kadar konuşabilmektedir (Kayaalp, 2006: 129). Dil gelişiminin önündeki engellerden biri dilin konuşma, dinleme, okuma veya gramer bilgisi gibi bir kısmına gereğinden fazla önem vermektir. Halbuki bir kısma fazla önem vermek dili ayakta tutan diğer sütunları ihmal etme anlamına da geleceğinden bu durum dilin bütüncül gelişimine ve fonksiyonelliğine zarar verir. Dilin bir cüzüne veya dildeki bir aşama üzerinde fazlaca geçirilen süre dil öğreniminde zaman kaybına yol açar.

Bir kelimenin akılda kalabilmesi, bir bağlam içinde zihnin ona olan ihtiyacının sağlanması ile olur. Aksi halde hafıza, o kelimeyi dışlar ve sonunda kişi o kelime veya bilgiyi unutur. Hazır bilgiler bir ihtiyaçtan tevellüt etmezler. Zihnimiz ihtiyaç duymadığı bilgilerden kurtulmak için unutur ve sürekli ihtiyaç duyacağı alana doğru gitmekle meşguldür. Yani zihin dünyamız ihtiyaç duyduğu veya ihtiyaç duyacağını hissettiği bilgilerin peşine düşer. Lakin şartlanma ile ve belli bir maksat ile öğrendiğimiz bilgiler, şart ve maksat ortadan kalkıp yok olduğunda zihnin ihtiyaç duymadığı bilgiler kategorisine girer. Başka bir deyişle o bilgiler hafızamızın çöp kutusundaki yerini alır.

Dil vasıtadan başka bir şey olmayıp insan için önemli olan dil ile anlatılan şeydir. Dilin günümüzde hala açıç̧a ortaya konamayan birçok yönü vardır (Kayaalp, 2006: 129). Zihin haritalama tekniğinin amacı, dilin özünde var olan hissi, zihin dünyasına yansıtmaktır. Yine bu teknikte amaç, öğrencinin keşfetme kabiliyetini geliştirmek ve güçlendirmektir.

Yukarıda ifade edildiği üzere bu teknikte ikinci aşamadan itibaren, anlamı tahmin edilen veya birden çok rastlanıldığı düşünülen kelimelere bakılması tavsiye edilir. Böylece dilde hem asıl olan mana ve suretler zarar görmez hem de kişi, seviyesi ilerledikçe kelimeler üzerinde tahmin etme kabiliyeti güçlenir ve lügate bağımlı olarak metin okuma ve dinleme yapmaktan kurtulur. Öğrenci, tahmin etme kabiliyetini geliştirdikçe dil üzerinde zihinsel hakimiyet kurar ve mana / suretler gelişim gösterir. Yavaş yavaş yeni bir dünya inşası bu metotla meydana gelir.

Diğer bir deyiş ile bu tekniğinin amacı kendi anadilimizde oluşan zihni kurguyu, öğrenilmesi hedeflenen yabancı dilde oluşturup geliştirmektir. Bu teknikte zihni kurgu geliştirilirken şöyle bir yöntem takip edilir.

Metindeki mana ve suretleri / anlatılmak istenen anlamı tahayyül etme.

Hedef metindeki mana ve suretler üzerinde tasarrufta bulunma ve manayı tespit etme.

Bu yöntemin takip edilmesi, bir kelimenin ikinci, üçüncü vb. hakiki veya mecazi anlamlarına geçişin sağlanması açısından önemlidir. Ayrıca zihin haritalama sistemi, zihni kurguyu geliştirip bilimselliğin olmazsa olmazı olan hayal gücünün kuvvetlenmesi tezini destekler. Böylece kelimede kastedilen mananın hakikat mi, mecaz mi yoksa kinaye mi olduğu daha hızlı anlaşılır.

Bir kelimenin birden çok anlama gelmesi o dildeki bir kusur olmayı aksine o dildeki ifade gücünün güçlü bir öze ve pozitif bir kudrete sahip olduğunun göstergesidir (Kayaalp, 2006:72). Okunan 
metinlerde veya dinlenen içeriklerdeki ifadeler dili kullanan kimsenin tercihine ve yazma konusuna göre hakiki, mecazi veya temsili anlatım noktasında değişkenlik gösterir. Örneğin edebi metinlerde mecazi ve temsili ifadeler diğer metinlere göre daha çok olup manayı güçlendirmeye yöneliktir. Bu tür ifadeleri anlamak cümle ve paragraf odaklı okuma ve dinleme yapmayı zaruri kılar.

Bilimsel metinlerde ise konuyu bilmek metnin anlaşılması için önemlidir. Anadilimizde, üzerine okuma yapmadığımız ve fikri olarak hakim olmadığımız konular ile ilgili olarak yabancı dilde okuma yaptı̆̆ımızda kelimelerin anlamlarını bilsek bile konu anlaşılmayabilir. Bunun nedeni ise yukarıda ifade edildiği üzere o konu ile ilgili resmin / suretin zihnimizde var olmamasıdır. Aksine çok hakim olduğumuz bir konu ile ilgili yabancı dilde metin okuduğumuzda bazı kelimelerin anlamını bilmesek bile, zihnimizde var olan net suretlerin etkisi ile sanki o kelimelerin anlamları bize biliyormuş gibi gelir. Bu tarz metinlerde yaptığımız tahminler çoğunlukla doğru çıkar. Bunun sebebi de yine zihni suretlerdir.

\section{Kullanım sıklığına göre zihin haritalama tekniği ile dinleme yapma ve metin okuma}

Aristoteles, ruhtaki teessürlerin sembolünün sesler olduğunu açlklar. Böylece dil, düşüncelerin olduğu gibi, sevincin, öfkenin, hüznün, arzuların vb. ruhtaki etkilenimin dışa vurma vasıtasıdır (Altınörs, 2014: 33). Bir dil, ses ile anlamı belirli bir biçimde birleştirir (Chomsky, 2002: 173). Eğer dil bir kağıda benzetilirse düşünce kağıdın ön yüzü, ses ise arka yüzüdür. Kâğıdın ön yüzü kesilirse ister istemez kağıdın arka yüzü de kesilmiş olur. Dilde ne ses düşünceden ne de düşünce sesten ayrılabilir (Kayaalp, 2006: 78). İnsan sesi biçimli, ölçülü ve ahenklidir. Dil sözcük var ederken en çok insan sesinden yararlanır (Koç ve diğerleri, 2009: 101). Diğer bir deyişle lafızlarda manayı belirginleştiren şey sestir. Gerçekte dillerin yapıları, anlam yapılarına göre daha bireysel yapılardır. Bu sebeple dillerin ses yapıları çok çeşitli ve değişken olup bu değişkenlik hem ses hem de anlam yapılarında gerçekleşmektedir (Karaağaç, 2013: 221). Sesler, kelime ve terkiplerin ruhlarıdır. Duygularımızı daha iyi ifade etmek, düşüncelerimizin daha anlaşılır kılmak, karşımızdakileri daha çok etkileyebilmek için sesimiz yer yer daha baskılı / vurgulu olur (Koç ve diğerleri, 2009: 164). Gerçekte mana vurgudadır. İnsan duymadığı kelimeleri tekrar ederek akılda tutamaz. Surete ihtiyaç vardır. Suret ise ses, görsellik, okuma yapma ve yazı yazma ile oluşur. Zihni suretlerin açığa çıkması için dinlemenin okuma gibi önemsenmesi gerekir. Zihin haritalama tekniğinde dinlemenin günlük süresi, günlük okunan metinlerin süresi olarak belirlenir. Hatta kimi zaman içerik dinleme süresi, okuma süresinden fazla da olabilir.

Dinleme, temel dil becerileri arasında en sık kullanılan dil becerisidir. Bir araştırmaya göre insan bir gününün \%9'unu yazarak, \%16'sını okuyarak, \%30'unu konuşarak \%45'ini dinleyerek geçirir (Onan, 2013: 86). Dinleme, hayatımız boyunca kullandığımız bir dil becerisi olup bu becerinin geliştirilmesi önemlidir. İnsanlar bilgi birikimlerine daha çok dinleme vasıtasıyla ulaştıklarından, dinleme yapılmadan konuşmanın olması neredeyse mümkün değildir. Kişi, yoğun dinleme ve okuma yapması sonucunda konuşma kendiliğinden ortaya çıkar Doğan, 2012: 96). Dinleme becerisi gelişim gösterdikçe kişi daha güzel konuşur. Dilin dört becerisinden en çok kullanılanı dinleme becerisidir. Fakat gelişmiş ülkelerde bile dinleme becerisi eğitimine gerekli ehemmiyet verilmemektedir (Koç ve diğerleri, 2009: 450-451). Bebekler anadillerini kelimelerdeki vurgulara ve muhataplarının jest ve 
mimiklerine dikkat kesilerek öğrenmektedirler. Bir kelimede kastedilenin hakiki mi yoksa mecazi mi olduğu muhatabın ses tonunda gizlidir (Doğan, 2012: 236).5

Günümüzde okuma ve dinleme ile online ortamda birçok siteye ve içeriğe ulaşmak mümkündür:

Özellikle Youtube olmak üzere internet ortamındaki programlar, belgeseller, dersler, TV kanalları

Gazete ve dergiler, süreli yayınlar, makaleler vb.

Okumanın amacı, okunan metinleri doğru ve hızlı bir şekilde anlamaktır. İyi bir okuma seviyesine ulaşmak için zihnin belli bir algılama ve düşünme düzeyine ulaşması gerekir (Koç ve diğerleri, 2009: 415). Metin okuma ve dinleme yaparken sağllk, ekonomi, spor, siyaset, teknoloji vb. gibi belli periyotlarla / aralıklarla farklı farklı konular okumak ve dinlemek dilin gelişimi açısından önem arz etmektedir. Zira belli konulara aşina olan zihin yeni bir konu ile karşılaştığında veya dinlediğinde yabancılık çekmekte ve bildiği kelimeleri alana uyarlarken zorlanmaktadır. Ayrıca belirli bir alan ile ilgili okuma ve dinleme yaparken manaya direkt etkide bulunan kelime ve terkipleri belirleyip bunlar üzerinde düşünmek metnin bütünselliğini anlama noktasında önemlidir.

Bir dilde kelimeyi tek başına almak, onu canlı ve sürekli olandan soyutlamak demektir. Böylece bir kelime, yalnız bir tarafıyla görünen ve bütündeki yeri kavranamayan cansız bir hale gelir. Kelimeler sadece hafızaların eseri olmayıp ruh, kelime kurmanın anahtarlarını adeta içgüdüsü gibi içinde taşır (Kayaalp, 2006: 72). Bu teknikte kişi, yabancı dilin haleti ruhiyesini anlamaya çalışır. Nasıl ki bireyin anadili onun dünya algısını ve neticede davranışlarını etkiliyorsa (Karakaya, 2007: 40) öğrenilen dil de kişinin düşünce dünyasını / algısını ve davranışlarını etkiler. Bu etki ile kişi, daha önce ilgi duymadığı konu ve alanları merak ederek ve fotoğrafik hafıza tekniklerinden (Vahapoğlu, 2012: 91) ${ }^{6}$ faydalanıp kendisine ilginç gelen şeylere yönelerek (Vahapoğlu, 2012: 91) yeni bir dünya inşa etmeye çalışır. Yeni bir dünyanın inşa edilebilmesi için, yabancı dil ile alakalı farklı sahaların taranması, okunması / gözden geçirilmesi önemlidir. Böyle bir tarama yapıldığında, öğrenilen dil ile düşünen insanların sevinçleri, hüzünleri, merakları, hayattan beklentileri, bize olan benzerlikleri ve bizden farklılıkları anlaşılmış olur.

Bir dili sözlü veya yazılı olarak kullanmak sözcükleri yan yana getirmek demek olmayıp yazılanlardan sadece bir anlam çıkarmaya çalışmak da yeterli değildir. Kişilerin veya nesillerin dile olan etkileri ve onda meydana getirdikleri değişiklik şekillerin kendisinde değil, o şekillerin başka biçimlerde kullanılmasında ortaya çlkar (Kayaalp, 2006: 136). Duyduğumuz veya okuduğumuz ve anlamını bilmediğimiz kelimeler zihnimizde işitsel, görsel duyusal vb. yardımlarla depolanarak (Tarcan, 2004: 11) tabiri caiz ise kuluçka dönemine girer ve kuluçka döneminde kelimelerin metinlerde ve sesli içeriklerde kullanım sıklığına göre zihnimizde veri tabanı oluşturulur. Her aşamada geçirilen süreye paralel olarak zihni yoğunlaşma sağlandığında, daha önce tanışlan kelimeler arasında bir sinıflandırma meydana gelir. Bu sinıflandırmaya göre çokça karşılaşılan ve manası üzerinde tahmin yürütebileceğimiz kelimelerden başlayarak sözlüğe bakılabilir. Zihin haritalama tekniğine göre sözlüğe bakarken çokça karşılaştığımız kelimelerden başlayarak az karşılaştığımız kelimelere doğru bir hiyerarşi izlenmesi önemlidir. Yani öğrenci bir kelime çok karşılaşıyorsa artık o kelime için sözlüğe bakılabilir.

\section{Kullanım sıklığına göre zihin haritalama yaparak konuşma ve yazı yazma}

5 Tüm fiziksel tepki dil öğretim yönteminde jest ve mimiklerin etkin bir öğretim aracı olarak kullanılması ile ilgili olarak
bk.

$6 \quad \mathrm{Bu}$, sadece kelime öğrenme ve öğrenilen kelimeleri unutmama için kullanılan bir tekniktir. 
Dil temsili tecrübenin bir şeklidir ve konuşmak için öncelikle realiteyi tecrübe etmek ve sembolleştirmek gerekir (Karakaya, 2007: 48). Çoğu zaman bir dili bilip bilmediğimiz o dili ne derece konuştuğumuz ile ölçülse de (Aktaş-İşigüzel, 2013: 39) yabancı dilde dinleme ye bağlı belli bir yoğunlaşma gerçekleşmeden doğal ve akıcı bir konuşma zordur. Kişinin iyi bir şekilde konuşabilmesi için bilgiyi beyinde düzenli bir şekilde depolaması lazımdır. Zira insan gerektiği yerde hızlı ve düzenli bir şekilde bu bilgileri dışa aktaracaktır (Koç ve diğerleri, 2009: 498). Hayat döngüsünde canlılar için yoğunlaşma olmazsa olmaz bir olgudur. Kâinatta her şey yoğunlaşma ile oluşur ve gelişir. Bilimsel alanlarda olduğu gibi dil öğreniminde de zihinde mana ve suretlerin oluşması, belirginleşmesi ve gelişimi için yoğunlaşmaya ihtiyaç vardır. Zihindeki yeni bilgi parçacıklarının birbiriyle bütünleşmesi ve o bütünleşme ile yeni ifade biçimlerinin ortaya çıkması için alana yoğunlaşmak ve zihni yormak önemlidir. Bu şekilde zihin kendi kapasitesinin üstüne çıkar ve bu yoğunlaşmaya bağlı olarak akıcı bir şekilde okuma becerisi kazanılır.

Okuma ve dinleme boş bir kabı doldurmaya benzer. Taşma süreci kendisini konuşma ile gösterir. Yazı ile son noktaya / zirveye ulaşır. Eğer cümle kalıplarını ezberlemeden akıcı bir şekilde yabancı bir dili konuşmak istiyorsak bu kabın taşmasını beklememiz en doğrusudur. Hafızamızın henüz ihtiyacını hissetmediği kaptaki fazlalık bilgiler, hafızamız tarafından unutulduğundan sürekli yeni okumalar ve dinlemeler yapmaya ihtiyaç vardır. Ayrıca dinleme ve okuma yapmak sureti ile zihinde gidip gelen mana ve suretler yabancı dili akıcı konuşturan etkenlerdir. Bu sayede zihnimiz birçok kelime ve kelime öbekleri arasında tercih yapma firsatı bulabilir.

Dilin karakteristik biçimi en küçük öğelerin her birine bağlı olup bu öğeleri tam olarak görmek için yeniden bütüne dönmek gerekir. Dilin sadece gramerle anlaşlamayacağ bulmak için dilin sınırlarını aşmak lazımdır (Kayaalp, 2006: 66). Dilin ilk aşamasından itibaren gramer bilgisi ekseninde düzgü konuşmaya çalışan birey dilin doğallığından uzaklaşmakta ve bu şekilde çalışan kişinin zihin dünyası bildiği birçok kelime arasında beynin yapması gereken tercih yapma işlevselliğini kullanamamaktadır. Bu tekniğe göre dil çalışılırken, bilimsel ilerlemenin olmazsa olmazı olan risk faktörü (Doğan, 2012: 281) her zaman göz önünde bulundurulmalı, yanlış okuma ve konuşmalar müsamaha ile karşılanmalıdır. Dil öğreniminde yanlış tercihler doğruya ulaşmak için hayati önem taşır.

Yazı dilinin konuşma dilinden daha düzenli olması genellikle yazının dilin ötesinde bir saygınlığa ulaşmasına sebebiyet vermiştir. Dahası bazı kimseler daha da ileri giderek dili, yazı dili olarak tanımlayarak konuşma dilini daha önemsiz görmüssler ve ona ikincil bir önem atfetmişlerdir (Karaağaç, 2013: 602). Oysa yabancı dilde yazı yazma kabiliyeti de, okuma ve dinleme ile dilde oluşan bu taşma sonucunda gelişir. Gramer bilgisine en çok yazı yazarken ihtiyaç duyulduğundan bu tekniğe göre gramer bilgisinin ağırlıklı olarak ilk aşamadan sonra, parça parça ve ihtiyaç bağlamında verilmesi uygun görülür.

\section{Kelimelerin kullanım sıklığına göre sınıflandırılması}

Bir dilde tüm kelimeler aynı düzeyde kullanılmadığından, hafızamız kullanım sıklığına göre kelime ve ifadeleri kategorize eder. Hafızamızda oluşan bu aşamaları dört seviyede kategorize etmek mümkündür:

Birinci seviye: Çok kullanılan kelimeler: Bu kelimeler konuşma dilinde sıkça kullanılan ve yabancı dilin kendisi üzerine temelleneceği kelimelerdir. 
İkinci seviye: Normal düzeyde kullanılan kelimeler: Bu kelimeler medyada ve metinlerde karşımıza çıkan ve orta ölçekte düşünce ve fikirler ile birlikte sıkça karşılaşılan kelimelerdir.

Üçüncü seviye: Az kullanılan kelimeler: Bu kelimeler ilmi metinlerde ve üst düzey fikir ve düşünceler ifade edilirken karşımıza çıkan daha spesifik anlamı olan kelimelerdir.

Dördüncü seviye: Nadir kullanımı olan kelimeler: Daha çok edebi ve ilmi metinlerde betimleme veya tasvir yoluyla karşılaşılan kelime ve ifade biçimleridir.

Edebi metinler, yabancı dilde mana ve suretlerin güçlenmesi açısından hayati önem taşır. Konusu birbiriyle bağlantılı ve sürükleyici uzun bir hikâye, bütünsellik içinde okuyucuyu yormadan anlamı bilinmeyen birçok kelimenin bilinmesine katkıda bulunur. Her fikrin arka planında bir hikâye vardır. Nitekim insanlar hikayeler ile düşünür (Doğan, 2012: 248).

Zihnin, kelimeleri kullanım sıklığına göre kategorize etmesi için dilin ilk aşamasından itibaren öğrencinin herhangi bir materyalden yardım almadan bir süre serbest bir şekilde metin okuma ve dinleme yapması önemlidir. Bu süre kişiden kişiye ve kişinin yabancı dile yoğunlaşma süresine göre farklılık gösterebilir. Zihnimiz bu süreç tamamlandığında normal sıklıkta kullanılan kelimeleri, az ve nadir kullanımı olan kelimeleri algılar ve kelimelerin kullanımı ile ilgili fikir yürütebilecek seviyeye ulaşır.

Ezber, bilgiyi aktarma faaliyeti olarak karşımıza çıkar ve genel olarak dilin düşünceden yoksun olduğu alanlarda gerçekleşir (Onan, 2013: 109). Yukarıda ifade edildiği üzere tüm kelimeler aynı sıklıkta kullanıma haiz değildir. Zihnimiz bir kelimeyi sözlüğe baktığımız halde unutuyorsa, bu hala o kelime ile ilgili zihni ihtiyacın tam gerçekleşmediği anlamına gelir. İhtiyaç duyulmayan bilgiler zihne yüklendiğinde hem o bilgiler zihnin kavrama yetisine zarar verebilmekte, hem de kişi bağlamından kopuk bir şekilde ezberlediği kelime ve cümleleri unutabilmektedir. Bu noktada yapmamız gereken şey, öğrenilen dildeki anlamı bilinmeyen kelimelere zihnin merakı / dikkat çekmesi sağlanması için bütünsellik içinde o kelimelere bir mühlet / süre vermektir (Doğan, 2012: 180).

Şu halde dil öğreniminde atılacak önemli adım, birinci seviyeden itibaren zihni sinıflandırmayı güçlendirerek kelime ve cümlelerin kuluçka dönemine girmesini sağlamak ve zihinde oluşan bu haritaya göre hafizaya ihtiyacı olan bilgileri yüklemektir. Her dilde mecaz, kinaye olgusu ve temsili anlatımlarla dolu beliğ ifadeler vardır. Arapçada kelimeleri harekesiz okuyabilmek için öğrenilen nahiv ilmindeki zorluk, İngilizcede yerini kelimeleri okuyabilmek için işitme zorunluluğu olmasında ve yazıldığı gibi okunmamasında, Türkçede ise sondan eklemeli bir dil olmasında kendisini gösterir.

Dilin yüzyıllardır zamana bağlı akışında uğradığı gelişim ve değişimde, iç yapısından ve dış yapısından kaynaklı gelişmelerin önemli rolü vardır (Kayaalp, 2006: 69). Dünyadaki tüm diller geniş grup ya da ailelere ayrılır ve her biri, bir diğeri ile ilişkilidir. Örneğin birçok Avrupa dili ortak bir kökten türemiş ve Roman, Alman, Slav Fars Yunan vb. çeşitli alt gruplara ayrılmıştır. İngilizcenin Alman dilleri grubuna girmesi ile birlikte kendisinde Roman-Latin dilinden birçok kelime vardır. Bu değişimde işgal, kültür empoze edilmesi, izole olma vb. birden çok etken vardır (Vahapoğlu, 2012: 43-44). Bu ve benzeri etkenler dildeki sürekli var olan sirkülasyonun ve değişimin nedenlerindendir. Nasıl ki doktora giden ve farklı nedenlerden ötürü yürüme zorluğu çeken birine egzersiz hareketleri verildiğinde, kişi bulunduğu halden kurtulmak için ağrı ve sızılara katlanmak zorundaysa, bilimsel ilerlemede de aynı durumdan söz edilebilir. Bir seviyenin zorluğu ve külfeti çekilmeden bir üst seviyeye çıkılmaz ve zihin bir seviyeye alıştığında zihinde tembellik başlar. 
Bu tekniğe göre zihnin haritalama yapılması için ilk aşamadan sonra cüzden küle doğru olan (tümevarım) öğrenme metodundan vaz geçilerek (Doğan, 2012: 177)7 dördüncü seviye de dahil tüm seviyelerden metinler / okuma parçaları okunur / taranır. Hafızamız dilin tüm lokasyonunu / haritasını çıkartarak kendisine uygun ve en kısa yoldan hedefe hangi yolları kullanarak ulaşacağını belirler. Daha sonra hafizasında oluşan haritalama neticesinde dilde var olan külli resmi büyüterek haritayı keşfe başlar. Hafızanın edindiği bu haritada dilin kendine özgü şeması çıkartılır ve öğrenci tekrar ikinci seviyeye bilinçli bir şekilde geri döner (tümtengelim). Suretler ne kadar külli olursa akılda kalan kelime sayısı o derece fazla olur.

Dil öğrenim aşamaları kendi içinde dairesel döngü ile tamamlanır. Kişi bir aşamadaki döngüyü tamamladıktan sonra aynı döngüde devam etmemesi esastır. Biten döngüde atılan her tur / tekrarlanan her aşama, kişiyi o aşamaya daha çok bağlı kılar. Bu durum, kişiyi hakim olduğu ve bildiği alana gereğinden daha çok önem vermesine ve diğer aşama / alanlara yabancılaşmasına neden olabilir. Böyle bir sorundan kurtulmak için ilmi sahadaki bir döngüyü tamamlamadan iç içe geçecek şekilde yeni bir sahanın açlması ve yeni bir döngünün / döngülerin oluşturulması önerilir.

Başka bir ifade ile her ilmin veya herhangi bir fikri aşama ve seviyenin engelleyen, bağımlılık (Doğan, 2012: 288) yapan bir başka etkisi daha vardır. Bu menfi etki hafife alınıp görmezden gelindiğinde ilim yolculu bir aşamada kısır döngüye girmekte ve zamanla zihinde muhkem duvarlar örülmektedir. Bu duvarları yıkmak için iç içe geçen ve sonu gelmeyen yeni fikri döngüler oluşturmak bir çare olarak düşünülebilir.

Bu ilmi döngüler aşağıdaki gibidir:

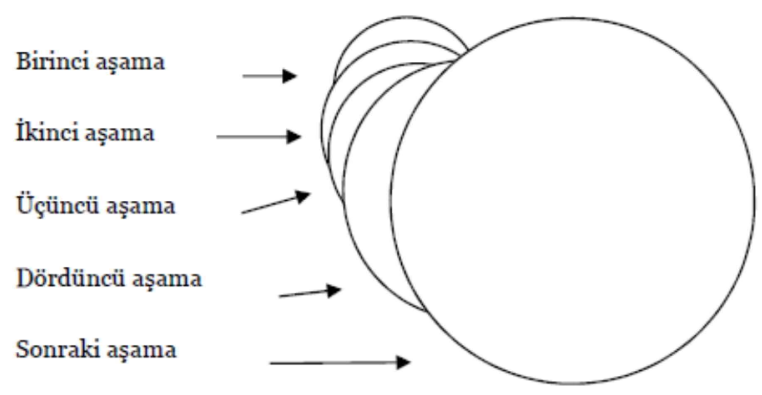

$\mathrm{Bu}$ durumda zihnin yorumlama ve gözlemleme kabiliyeti gelişim göstererek insan her aşama ve seviyede kendisine çizilen sınırları aşarak yaptığı dil öğrenim yolculuğu bilinmeyeni keşfetmeye doğru yol alır. Bu teknik ile öğrenilen yeni bilgiler kişiye farklı öğrenim sahaları açar.

$\mathrm{Bu}$ teknik ile çalışıldığında, kelime ve kelime öbekleri unutulurken öncelikli olarak nadir sıklıkta kullanılan kelimeler, sonra sırasıyla az kullanılan, normal düzeyde kullanımı olan kelimeler hafızadan silinir. Çünkü zihinde oluşturulan bu hiyerarşik yapıda her alt düzey, bir üst düzeyi koruyucu bir etkiye sahiptir. Yani nadir kullanımı olan kelimelerin akılda kalması için öğrencinin az kullanımı olan kelimeler düzlemiyle irtibatının güçlü olması gerekir. Aynı şekilde az kullanımı olan kelimelerin akılda kalması için normal kullanımı olan kelimelerle ilgili metinleri iyice anlayabilmek gerekir.

Öğretmenin bilmediği kelimeler bazen üçüncü seviyedeki kelimelerden, çoğunlukla ise dördüncü seviyedeki kelimelerden olur. Bu tekniğe göre dil öğrencisi, hocanın bilmediği kelimelerin doğal olarak çoğunlukla nadir kelimeler olduğunu algılayacağından hem kelimeleri hafızada tutma ile ilgili endişelenmeyecek, hem de hocasının bildikleri kadar bilmediklerinin de öğretici olduğunu bilerek öğrenim hayatını sürdürecektir (Doğan, 2012: 280). Yine bu tekniğe göre hocanın bilmediği kelimeler öğrenciler için iyi bir ipucu olduğundan bu şekilde derslerin daha rahat ve doğal bir ortamda geçmesi sağlanabilir. Özetle; zihin haritalama tekniği ile dil çalışan öğrencinin amacı, yabancı dili stabil ve

Bilişsel dil öğretim yönteminde tümevarım ve tümdengelim teknikleriyle dilbilgisi öğretimi ile ilgili olarak bk. 
matematiksel yöntem veya formüllerle öğrenmek değil, yabancı kültürü keşfetmektir. Bu sayede anadil ile oluşturulan zihni dünyanın yanına yeni bir zihin dünyası inşa edilir. Ayrıca bu teknikte pratik zeka değil, sosyal / duygusal zeka esastır (Doğan, 2012: 321). Temelde bu teknikte dilin gelişimi, kelime ve kelime öbekleri içinde yorumlama kabiliyetini geliştirme ve okunan metinleri, dinlenen parçalar üzerinde gözlem yapma esasına dayanmaktadır.

Bu tekniğe göre öğretici iyi bir bilgi aktarıcı olmaktan ziyade iyi bir gözlemleyici ve yönlendirici olup tıpkı yönetmenler gibi misyonunu, vizyonunu ve stratejilerini belirlemektedir (Aktaş ve İşigüzel, 2013: 14). Öğretici ve öğrenci, sınırları çizilmeyen ve istenildiğinde değişkenlik gösteren, her türlü şartlanmadan uzak bir öğrenme döngüsü içindedir. Kişi, belli aralıklarla yenilenen program dahilinde bunu yaparak alışılmışın / rutinin sebebiyet verdiği ataletten kendisini kurtarır.

Kelimeler yapbozun parçacıkları gibidir ve bu parçalardan tam bir resim meydana gelir. Okunan metinde suret tam ve net değilse kelimelerin ifade etmek istedikleri manalar da kapalı veya yetersiz olur. Yan yana gelen bir yapbozun parçacıkları ne kadar çok olursa resim o derece büyük olur. Kelimeler bir mana için vaz edilmiş lafızlar olup şeklen tek başlarına bir anlam ifade ederler. Aslında kelimelerin hakiki manaları yukarda değinildiği üzere zihni suretlerdir. Suretler insan zihninde düşünülen anlamlardır. Lafızların anlamlarını bulabilmek için aynı bağlamdaki diğer parçacıklara / lafızlara ihtiyaç vardır. Bir manaya delalet eden lafızlarda kastedilen mananın hakiki mi yoksa mecazi mi olduğu yine metinde çizilen resimden / suretten anlaşılır. Şu halde kelimeler tek başlarına boşlukta durmakta olup onları bağlamları içinde yerli yerine oturtacak şey, metinler ile çizilen suretlerdir. Bu teknikte amaç kelimelerin birbiri ardına dizilimi ile oluşan bu suretlere yoğunlaşmaktır ve dildeki suretlerin belirginleşmesini sağlamaktır, kelimelerin birincil ve ikincil anlamlarını akılda tutmak değil. Zaten anadilimizde kelime ve cümlelere değil, o kelime ve cümlelerin ne demek istediğine, başka bir ifade ile o kelime ve kelime öbekleri ile ne kastedildiğine bakılmaktadır.

\section{Sınav sistemine göre dil öğrenme ile kullanım sıklığına göre zihin haritalaması yaparak dil öğrenme karşılaştırması}

Günümüzde eğitim hayatında sınavların olmadığı bir alan neredeyse yok gibidir. Sinavlar ister dil ile ilgili olsun ister olmasın, bir şeyi bilip bilmediğimizin göstergesi olup sınavlardaki başarılarımız geleceğimizi büyük oranda şekillendirmektedir. Türkiye'de ve Dünya'nın birçok ülkesinde dil ile ilgili farklı seviyelerde sınavlar yapılmakta ve bu sınavlarda alınan puanlar gelecekteki iş ve akademik hayatımıza yön vermektedir.

Sınavlarda başarılı olmak için dil çalışan birey tüm kelime ve kelime gruplarını, aşama ve seviyelerine bakmaksızın psikolojik olarak tek sınıfmış gibi aynı derecede önemli görür. Halbuki sınav için çalışılan kelime ve ifade kalıpları bazen nadir olarak kullanılan, bazen de az kullanılan kelime ve ifade grubundandır. Yine bu kelimelerden bazılarının kullanımı bölgeseldir. Hatta kimi kelimelerin kullanım sıklığı da aynı dili konuşan ülkelerde farklılık göstermektedir. Herhangi bir kategorize yapmadan tüm karşılaştığı kelime ve kelime gruplarını önemli sayan hafızada bu durum karışıklığa neden olmakta ve kelimeler kullanım sıklığına göre zihinsel olarak sınıflandırılamamaktadır.

Örneğin YDS sınavında çıkan sorularda nadir kullanılan kelimeler olmakla birlikte çok kullanılan, orta sıklıkta kullanılan ve az kullanılan kelimeler vardır. Sınava çalışan kimse çıkmış soruları çözerken zihni sınıflandırma yapamadığından, hafızaya tüm kelimelerin önemli olduğu sinyali gönderilir. Çünkü sınavda çıkan tüm kelime ve ifadeler sınava girecek öğrenci için önemlidir. Oysa örneğin İngilizce ve 
Arapça ile ilgili olarak bu tür sınavlarda çıkan bazı kelimeleri kimi zaman üniversite eğitimi almış bir İngiliz veya Arap dahi bilememektedir.

Sınavda başarılı olma maksadıyla yabancı dilini geliştiren öğrenci, geçici hafızaya aldığı dili adeta ezberlemektedir. Bunun yanı sıra sınavlar, bilgiyi tekrarlama zorunluluğu getirdiğinden zihnin doğal unutma fonksiyonu zarar görebilmekte, kişi edindiği bilgileri devamlı olarak tekrar etme zorunluluğu hissetmektedir. Hatta böyle durumdaki öğrenci, alışkanlıkla unutmadığı bilgileri dahi tekrar etme ihtiyacı duyabilmektedir.

Dil öğreniminde kalıı başarının sağlanması ve öğrenilen bilgilerin aynı şekilde hafızaya yerleşmesi için bu teknikte, sınav vb. şartlanmadan uzak bir şekilde dil çalışılması önerilir. Böylelikle kalıcı hafızaya / bilinç altına doğru bilgi akışı gerçekleşir. Bilinç altı kurgu ve hikayeler ile yaşar. Dilin hikayesi ne kadar bilinç altını etkiler ve kelimeler ne kadar beliğ / sanatsal olursa o derece yabancı dil kalıcı olur.

İnsanlar anadilleri ile konuşup yazarken farkında olmadan karmaşık bilinçaltı gramer kuralları kullanırlar. Bir dili bilmek matematik formülleri gibi dil bilgisi kurallarını sıralamak anlamına gelmez. Yine bu bilgileri sıralayabilmek de dili konuşmayı sağlamaz. Sözcük seviyesinde bile karmaşı dil varyasyonları varken, kişinin cümle içindeki değişkenlikleri ezberleyerek çözümleyebilmesi mümkün görünmemektedir. Zira kişi, okuma ve dinleme yaparken dil bilgisi kurallarını düşünecek zaman bulamaz ve bu şekilde iletişim kuramaz. İletişim kursa bile bu iletişimi sürdüremez (Işık, 2013: 16-17). Ruhsal bağlantı kurabildiğimiz bilgiler bilinç altına ulaşarak düşüncemizden bir parça oluverir. $\mathrm{O}$ zaman zihnimizce işlenen bilgiler yeniden kompoze edilir.

Bir kimsenin uzu süreli belleğinde herhangi bir konu ile ilgili depoladığı bilgi, edinilmiş bilgi olarak tanımlanır (Onan, 2013: 96). Bilgi işlenirken kısa süreli bellek devreye girer. Bu belleğin işlevi, sınırlı bir zaman zarfında sınırlı miktardaki bilgiyi depolamaktır. Bu belleğe gelen bilginin zihinde kalış süresi çok kısadır ve bu bellekte duran bilgiler uzun süreli belleğe gönderilmediği takdirde çok hızlı bir şekilde unutulmaktadır. Kısa süreli bellekte bilgi akışı gerçekleşir. Daha sonra uzun süreli bellekte depolanmış bilgilerle karşılaştırlır, eşleştirilir ve bütünleştirilir. Uzun süreli hafızadaki bilgilerin organize bir şekilde içselleştirilmesinde kısa süreli bellek önemli rol oynar (Onan, 2013: 160). Uzun süreli hafıza, gerektiğinde kullanıma hazır olarak duran, birbiri ile organize bilgilerin depolandığı bir kütüphaneye benzetilmiştir. Bu kütüphanenin, hatırlamayı, bilgiye ulaşmaya imkan veren milyonlarca girişe ve bölmeleri arasında geçiş yapmayı sağlayan bir ağa sahip olduğu düşünülmektedir. Bu organize bilgiyi uzun süreli bellekten geriye getirmek ve yararlanmak çok kolaydır (Onan, 2013: 243; Doğan, 2012: 174-175).

Yukarda belirtildiği üzere bir kısa süreli hafıza, bir de uzun süreli hafıza vardır. Bir amaç ve hedef güdüldüğünde bilgi, hafıza tarafından özümsenemediğinden ve zihin mana ve suretler ile değil, bilgi parçacıklarıyla meşgul olduğundan bilgiler bilinç üstünde / kısa süreli hafızada kalır. Şart veya maksat gerçekleştiğinde ise bilinç üstünde / kısa süreli hafizada tutulan bilgiler zihin tarafından serbest bırakılır. Dahası zihnimiz çok önemli ile az önemli bilgiler arasında ayrım yapamaz.

Dil kursları, dil öğretim kitapları ve sözlüklerden yoksun olan insanlar yabancı dil öğrenirken muhatabın jest ve mimiklerine, el kol hareketlerine, ses tonuna, ifadenin siyak ve sibakına dikkat kesilmek zorundalardı. Çünkü sözlükten yardım alma gibi bir imkana sahip değillerdi. Günümüzde elektronik ortamda veya kitap olarak her an kullanıma hazır bekleyen sözlüğün bu konsantrasyonu 
bozan menfi bir etkisi olabilir. Aslında tüm yardımcı takviyelerin zihni tembelleştiren bir tarafı göz ardı edilmemelidir. Zihnimizin kapasitesini aşması için bir süre sonra bu ve benzeri yardımcı öğelerden kurtulması gerekir. Kendisine alışılan her yardımcı öğe uzun vadede zihninin aktivitelerini azaltır. Bu öğeler bacağı sakatlanan insanların kullandığı koltukaltı değneklerine benzer. O değnekler geçici süre ile insanı yürütse bile insanın tekrar yürüyebilmesi için öncelikle o değnekleri atması lazımdır. İşte kendi dinamikleriyle nasıl dil öğreneceğini keşfeden insanlar, anadilinde geçtiği merhalelere benzer şekilde bir süreçten geçerek dil öğrenmektelerdi (Doğan, 2012: 97).

\section{Sonuç}

Zihin haritalama tekniği, kelimelerin delalet ettiği mana ve resimleri temel almak sureti ile yabancı dil öğreniminde kelimelerle başlayan dil öğrenim yolculuğunu ilk aşamada desteklemiş; dört temel dil becerisi olan dinleme, okuma, konuşma ve yazma becerilerinin geliştirilmesi ve kişinin anadiline yakın bir anlama ve konuşma seviyesine ulaşması için kelimelerin kullanım sıklı̆̆ına göre zihinsel sınıflandırılmasını ve yabancı dildeki okuma biçimlerinin döngüsel tarzda ve iç içe geçmiş bir şekilde farklı seviyelerde okunmasını önererek diğer dil öğretim tekniklerine yeni bir veçhe kazandırmaya çalışmıştır. Bu yenilik, dil öğreniminde sıkça karşılaşılan dili öğrenme, ama daha sonra dili geliştirememe sorununu çözmeye ve öğrenciyi dil öğreniminde istediği seviyeye ulaştırmaya yöneliktir.

Bu teknik, kelimelerin özünde var olan hakikat mecaz ve kinaye olgularının göz ardı edilmeden kelimelerin bağlamının dikkate alınmasına, kelimelerin anlamlarını belirlemeye ve sözcüklerin kullanım sıklığına yönelik öğrencinin kelimeler ile ilgili tahmin etme kabiliyetini güçlendirme ve manayı tespit etme noktasında inisiyatif almalarına, dilin hissi yönünün geliştirilmesinin dil öğrenimindeki rolüne, lafızları zorlaştıran şeyin sadece sözcük dizilimi değil aynı zamanda metindeki mana yoğunluğu olduğuna ve dil öğrenimini aşama aşama bu tekniğe göre geliştiren kişinin sonunda hacimli bir kitap okuyacak seviyeye ulaşabileceğine bir bütünsellik içinde dikkat çekmiştir.

Yabancı dil öğreniminde zihnin faaliyetlerini güçlendirmek için alışılmış çalışma şeklini periyodik olarak değiştirmek, zihnin işlevselliğini maksimum düzeye çıkarmaktadır. Böylelikle zihinde çağrışım yapan izlenimler ve imgesel algllar donuklaşmadan sözcüklerin ilk anlamından sonraki anlam veya anlamlarına geçiş sağlanabilir. Ayrıca bu teknik, öğrencinin sözlüğe olan ihtiyacını minimum düzeye indirgemek için dil öğreniminde belirli evrelerden sonra kullanılan ve bağımlılık yapan tüm yardımcı öğelerden yavaş yavaş vazgeçilmesini, bir kelimenin sözlüğe bakılma evresi olduğunu, hafizanın yeni bir kelimeyi öğrendiğinde hemen kabul etmediğini, kabul etmesi için zihne tanıma firsatı verilerek onu hayal etmesinin ve imgeleştirmesinin beklenmesi gerektiğini, tıpkı anadilimizde olduğu gibi yabancı dil öğreniminde de zihni kurguyu ve hayal dünyasını geliştirmenin esas olduğunu vurgulamıştır.

$\mathrm{Bu}$ teknik, dinleme dil becerisinin gelişimine ayrı bir önem vererek bu dil becerisini diğer dil becerilerini besleyen ve kelimelerin kuluçka dönemine girmesinde / zihinsel veri tabanı oluşmasında etkili olan temel dil becerisi olarak görür. Okumanın zihinsel tümel örgünün oluşumundaki katkısı da en az dinleme kadar önemlidir. Konuşma ve yazı yazma dil becerileri ise dinleme ve okuma dil becerilerinin zihinsel olarak adeta taşması sonucu ortaya çıar. Konuşma evresinde öğrenciye müdahale edilmemesi ve öğrencinin gramer hatalarının müsamaha ile karşlanması öğrencinin doğal dil konuşma becerisi kazanmasına katkıda bulunur. Ayrıca ilk dil öğrenim evresinde konuşma ve yazı yazma dil becerilerine ağırlık verilmesi, öğrencide bilgilerin özümsenemeden ezberlenmesine yol açar ve o bilgilerin işlevsel hale gelmesi zorlaşır. Aynı şekilde gramer bilgisinin de zihinsel ihtiyaca binaen 
verilmesi hem gramer kurallarının çabucak unutulmasını önler hem de gramer konularının zihnimizce hızlıca kavranmasını sağlar.

Bu teknik ile çalışıldığına kullanım sıklığına göre hafızaya yerleşen kelimeler, hafızanın doğal unutma sürecinde de öğrenciye kolaylık sağlar. Bir kelimeyi neden unuttuğunu ve neden unutmadığını keşfeden kimse, dilde sıkça karşılaşılan tekrar etme sıkıntısından kurtulmuş olur. Daha da önemlisi öğrenci; edebi, bilimsel, vb. metinlere tümel bakış açısı ile bakarak ve metnin arka planını sezerek hangi ifade tarzları ile karşılaşacağını ve konuşurken eş anlamlı kelimeler arasından hangisini seçeceğine dair bağlam yardımı ile hissetme becerisi kazanır.

Son olarak sınava yönelik dil öğrenimin, zihnin yukarıda belirtilen ve bilinçaltında gerçekleştiği düşünülen zihnin doğal sınıflandırma sistemini bozduğu, dahası dili konuşanın jest ve mimiklerine, el kol hareketlerine, ses tonuna, ve kelimenin öncesi ve sonrasına ehemmiyet vermenin sözlük kadar etkili olduğu, bir maksat ve şartlanma ile dil öğreniminin dili, yaşayan bir gerçeklik olmaktan kopardığı ve dili suni kalıplar yığınlarına dönüştürdüğü, bazen YDS gibi sınavlar çalışılırken karşılaşılan, belki de öğrencinin ileri seviye edebi okumalar yaparken ancak karşlaşabileceği kelimeleri zihin, çok kullanılan kelimeleri aynı kategoriye aldığı ve bu durumun zihnin yorumlama ve değerlendirme yetisini geliştirmeyip aksine dil öğrenimini donuk bir hale getirdiği gözlemlenmiştir.

\section{Kaynakça}

Aktaş, T. ve İşigüzel, B. (2013). Erken Yaşlarda Oyunlarla Yabancı Dil Öğretimi Kuram ve Uygulama. Ankara: Nevşehir Üniversitesi.

Altınörs, A. (2014). 50 Soruda Dil Felsefesi. (2. Baskı). İstanbul: Bilim ve Gelecek Kitaplığı.

Barthes, R. (2013). Dilin Çalışma Sesi. (Çev. A. Ece.). İstanbul: Yapı Kredi.

Buzan, T. ve Buzan, B. (2018). Zihin Haritalarl, (7. Baskı). İstanbul: Alfa Basım.

Chomsky, N. (2002). Dil ve Zihin. (Çev. A. Kocaman). (2. Baskı). Ankara: Ayraç.

Demircan, Ö. (1988). Dünden Bugüne Türkiye'de Yabancr Dil. İstanbul: Remzi.

Doğan, C. (2012). Sistematik Yabancı Dil Öğretim Yaklaşımı ve Yöntemleri. İstanbul: Ensar.

Güler, İ. (Ed.). (2015). İslam Medeniyetinde Dil İlimleri, Tarih ve Problemler. İstanbul: İSAM.

Hânlerî, P. (2004). Düşünce ve Dil, (Haz. Hüseyin Su). (Çev. Sait Okumuş). Ankara: Hece.

Işık, A. (2013). Yabancı Dil Nasıl Öğrenilmez Nasıl Öğrenilir. (4. Baskı). Ankara: Elma.

Karaağaç, G. (2013). Anlam (Anlam Bilimi ve İletişim). İstanbul: Kesit.

Karakaya, Ş. (2007). Dil Gelişimi ve Dil Politikası. Ankara: Akçă̆.

Kayaalp, İ. (2006). İletişim ve Dil, Ankara: Türkiye Diyanet Vakfi.

Kılıç, V. (2002). Dilin İşlevleri ve İletişim. İstanbul: Papatya.

Koç, S., Yeniçeri, H., Yağcı, İ., Odacı, S., Deniz, K. ve Yıldız H. (2009) Üniversiteler İçin Dil ve Anlatım, (2. Baskl). Konya: Palet.

Onan, B. (2013). Dil Eğitiminin Temel Kavramları. (2. Baskı). Ankara: Nobel Akademik.

Saussure, F. (2014). Genel Dilbilim Yazıları. (Çev. Savaş Kılıç). İstanbul: İthaki.

Tarcan, A. (2004) Yabancı Dil Öğretim Teknikleri. Ankara: Nobel.

Vahapoğlu, E. (2012). Yabancı Dil Öğrenme Yolları. (9. Baskı). İstanbul: Alfa. 